\title{
Excitability of the motor cortex to magnetic stimulation in patients with cerebellar lesions
}

\author{
V Di Lazzaro, D Restuccia, M Molinari, M G Leggio, R Nardone, D Fogli, P Tonali
}

Department of Neurology, Catholic University, Rome, Italy

V Di Lazzaro

D Restuccia

M Molinari

M G Leggio

$R$ Nardone

D Fogli

P Tonali

Correspondence to:

Vincenzo Di Lazzaro,

Istituto di Neurologia,

Università Cattolica,

Policlinico Gemelli, L go A

Gemelli 8,00168 Rome,

Italy.

Received 18 January 1993

and in revised form

9 March 1993.

Accepted 7 April 1993

\section{Abstract}

The excitability of the motor cortex to magnetic stimulation was evaluated in seven patients with cerebellar lesions (six patients with a unilateral lesion) and in 20 control subjects. Magnetic motor threshold was defined at rest. In all but one of the patients with a hemicerebellar lesion the threshold was higher in the motor cortex contralateral to the impaired hemicerebellum and the right/ left threshold asymmetry was clearly greater than normal. In the patient with a lesion involving both cerebellar hemispheres the magnetic threshold was above the normal limit on both sides. The latencies of motor responses were normal in all patients. This increase in the magnetic threshold of the motor cortex functionally related to the impaired hemicerebellum suggests the existence of a facilitating tonic action of the cerebellum on central motor circuits that might act at the cortical, or spinal level, or both.

$(\mathcal{F}$ Neurol Neurosurg Psychiatry 1994;57:108-110)
The functional relations between cerebellar structures and cerebral cortex have been widely investigated in experimental animals and it has been shown that excitability of the motor cortex is modified by cerebellar lesions (for review, see ${ }^{1}$ ). The introduction of the technique for magnetic transcranial stimulation of the motor cortex has made it possible to investigate, non-invasively, central motor circuits in humans. ${ }^{2}$ The present study was designed to elucidate the influence of cerebellar diseases on motor cortex excitability in humans.

\section{Patients and methods}

We studied 20 normal subjects (mean age 53.1 (SD 19.9); range 24-84 years; 13 men) and seven patients with acquired cerebellar lesions (mean age 54.5 (SD 17.4); five men); six patients with a unilateral cerebellar lesion and one with a bilateral cerebellar lesion. We selected these patients on the basis of clinical and neuroradiological evidence of isolated cerebellar lesions without involvement of other central nervous system structures (table 1).

Table 1 Clinical and neuroradiological findings

\begin{tabular}{|c|c|c|c|c|c|c|}
\hline $\begin{array}{l}\text { Patient } \\
\text { No }\end{array}$ & Age & Sex & $\begin{array}{l}\text { Neuroradiological } \\
\text { findings }\end{array}$ & $\begin{array}{l}\text { Presenting signs } \\
\text { and symptoms }\end{array}$ & $\begin{array}{l}\text { Neurological findings } \\
\text { on electrophysiological } \\
\text { study }\end{array}$ & $\begin{array}{l}\text { Time from onset to } \\
\text { electrophysiological } \\
\text { study }\end{array}$ \\
\hline & & & & Unilateral cerebellar lesion & & \\
\hline 1 & 48 & $\mathbf{M}$ & $\begin{array}{l}\text { Absence of left } \\
\text { hemicerebellum }\end{array}$ & $\begin{array}{l}\text { Left hemifacial spasm, } \\
\text { dysmetria }\end{array}$ & $\begin{array}{l}\text { Left hemifacial spasm, slight } \\
\text { dysmetria of the left upper } \\
\text { limb }\end{array}$ & 1 year \\
\hline 2 & 78 & $\mathbf{M}$ & $\begin{array}{l}\text { Ischaemic lesion in the } \\
\text { territory of the left posterior } \\
\text { inferior cerebellar artery }\end{array}$ & Vertigo, ataxia & $\begin{array}{l}\text { Impairment of the check reflex } \\
\text { in left upper limb }\end{array}$ & 2 months \\
\hline 3 & 65 & $\mathrm{~F}$ & $\begin{array}{l}\text { Cyst of the left cerebellar } \\
\text { hemisphere }\end{array}$ & $\begin{array}{l}\text { Ataxia, headache, } \\
\text { vomiting }\end{array}$ & Ataxia & 1 month \\
\hline 4 & 64 & $\mathbf{M}$ & $\begin{array}{l}\text { Ischaemic lesion in the } \\
\text { border zone of the left } \\
\text { posterior inferior cerebellar } \\
\text { artery }\end{array}$ & $\begin{array}{l}\text { Ataxia, hypotonia, } \\
\text { headache, vomiting, } \\
\text { vertigo }\end{array}$ & Dysmetria & 8 months \\
\hline 5 & 40 & $\mathbf{M}$ & $\begin{array}{l}\text { Ischaemic lesion in the } \\
\text { territory of the right anterior } \\
\text { inferior cerebellar artery }\end{array}$ & $\begin{array}{l}\text { Dysmetria, hypotonia, } \\
\text { vomiting, vertigo, } \\
\text { nystagmus }\end{array}$ & Slight dysmetria & 1 month \\
\hline \multirow[t]{2}{*}{6} & 32 & $\mathbf{M}$ & $\begin{array}{l}\text { Haemorrhagic infarct in the } \\
\text { territory of the lateral branch } \\
\text { of the left superior cerebellar } \\
\text { artery }\end{array}$ & $\begin{array}{l}\text { Headache, vomiting, } \\
\text { lateropulsion }\end{array}$ & None & 1 year \\
\hline & & & & Bilateral cerebellar lesion & & \\
\hline 7 & 42 & $\mathbf{F}$ & $\begin{array}{l}\text { Ischaemic lesion in the } \\
\text { territory of the left superior } \\
\text { cerebellar artery and a } \\
\text { watershed infarct in } \\
\text { boundary zone between the } \\
\text { right anterior inferior } \\
\text { cerebellar artery and superior } \\
\text { cerebellar artery }\end{array}$ & $\begin{array}{l}\text { Headache, vomiting, } \\
\text { vertigo, drowsiness }\end{array}$ & $\begin{array}{l}\text { Slight dysmetria of the left } \\
\text { upper limb }\end{array}$ & 1 month \\
\hline
\end{tabular}


Table 2 Electrophysiological findings

\begin{tabular}{|c|c|c|c|c|c|c|}
\hline \multirow[b]{2}{*}{$\begin{array}{l}\text { Patient } \\
\text { No }\end{array}$} & \multirow[b]{2}{*}{$\begin{array}{l}\text { Side of } \\
\text { cerebellar lesion }\end{array}$} & \multicolumn{3}{|c|}{$\begin{array}{l}\text { Resting motor threshold } \\
\text { (\% maximal magnetic stimulator output) }\end{array}$} & \multicolumn{2}{|c|}{$\begin{array}{l}\text { Central motor } \\
\text { conduction time (ms) }\end{array}$} \\
\hline & & Right & Left & $\begin{array}{l}\text { Difference } \\
\text { between sides }\end{array}$ & Right & Left \\
\hline \multicolumn{7}{|c|}{ Unilateral cerebellar lesion } \\
\hline 1 & Left & 60 & $77^{\star}$ & $17^{\star}$ & $9 \cdot 6$ & $9 \cdot 7$ \\
\hline 2 & Left & 50 & 65 & $15^{\star}$ & $8 \cdot 7$ & $8 \cdot 5$ \\
\hline 3 & Left & 50 & $85^{\star}$ & $35^{\star}$ & $7 \cdot 7$ & $7 \cdot 6$ \\
\hline 4 & Left & 65 & $85^{\star}$ & $20^{\star}$ & $8 \cdot 2$ & $8 \cdot 3$ \\
\hline 5 & Right & 65 & 40 & $25^{\star}$ & $8 \cdot 1$ & 8 \\
\hline 6 & Left & 54 & 52 & 2 & $7 \cdot 7$ & $7 \cdot 8$ \\
\hline \multicolumn{7}{|c|}{ Bilateral cerebellar lesion } \\
\hline 7 & & $92^{\star}$ & $87^{\star}$ & 5 & $9 \cdot 1$ & 9 \\
\hline \multicolumn{7}{|c|}{ Upper normal limits (mean plus 2.5 SD) } \\
\hline & $\mathbf{7 4} \cdot 4$ & & & $9 \cdot 2$ & $12 \cdot 4$ & \\
\hline
\end{tabular}

${ }^{\star}$ Increased value.

\section{NEUROPHYSIOLOGICAL PROCEDURES}

Transcranial magnetic stimulation of the motor cortex was achieved with a Magstim 200 (Novametrix, UK). The magnetic pulses were delivered through a $120 \mathrm{~mm}$ circular coil. The maximum magnetic field generated was about 2 tesla at the coil centre. The coil was centred over the vertex. To obtain a preferential activation of each hemisphere, a clockwise inducing current flow, as viewed from above, was used for the right motor cortex and a counter clockwise flow for the left motor cortex. ${ }^{3}$ Contralateral to the preferentially activated motor cortex compound motor action potentials (CMAPs) were recorded from the abductor digiti minimi (ADM) muscle through surface electrodes and amplified with filter settings of $2 \mathrm{~Hz}$ and $5 \mathrm{kHz}$. We defined resting motor threshold (RMT) as the minimum stimulus intensity that evoked $100 \%$ responses in 20 consecutive stimulations while recording from relaxed muscles. The difference for RMT between sides was evaluated in controls and in patients.

The latencies of the motor responses after cortical stimulation were measured in patients and in control subjects with target muscles relaxed at an intensity equal to the maximal power allowed by the device employed. Relaxation of the muscle was monitored by audiovisual EMG feedback. To evaluate only the central component of the conduction time from scalp to muscles we calculated the central motor conduction time (CMCT) by subtracting the peripheral component from the latency of CMAPs after cortical stimulation. The peripheral motor conduction from the spinal cord to muscles was estimated by performing a magnetic stimulation on the cervical spine.

Normal limits for RMT and for CMCT were defined as mean \pm 2.5 standard deviations of the values in controls.

\section{Results}

Table 2 summarises the neurophysiological findings.

\section{CONTROL SUBJECTS}

The RMT for evoking a CMAP in the contralateral $\mathrm{ADM}$ muscles ranged between $35 \%$ and $68 \%$ of the maximal magnetic stimulator output (mean 51.1 (SD 9.3)) with a mean difference between sides of 3.3 (SD 2.4); range $0-8$. The mean $\mathrm{CMCT}$ was $9 \cdot 7 \mathrm{~ms}$ (SD $1 \cdot 1)$; range $7 \cdot 7-12$.

\section{UNILATERAL CEREBELLAR LESION}

In all but one patient (patient 6 , table 2) with a unilateral cerebellar lesion the RMT was higher in the motor cortex contralateral to the impaired hemicerebellum than in the motor cortex contralateral to the preserved one and the right/left RMT asymmetry was clearly above normal limits. The CMCT was within normal limits bilaterally in all patients (table 2).

BILATERAL CEREBELLAR LESION

In the patient with a lesion involving both cerebellar hemispheres the RMT was bilaterally higher than normal with no significant right/left RMT asymmetry. The CMCT was within normal limits (table 2).

\section{Discussion}

An interesting result of the present study is the reduction of the excitability of the motor cortex contralateral to the impaired hemicerebellum, shown by the enhancement of the RMT. The abnormal increase of the RMT is particularly evident in the comparative study of the two sides in cases of unilateral cerebellar lesion. A similar finding has been reported by Caramia et al for patients with spinocerebellar ataxia. ${ }^{4}$ The association of pyramidal deficits in their patients interfered with a definite explanation of this phenomenon, however, whereas in our patients clinical and neuroradiological findings and CMCT measurement ruled out an involvement of central motor pathways. The present data suggest the existence of a facilitating tonic action of the cerebellum on central motor pathways. Luciani $^{5}$ first proposed that the cerebellum exerts a tonic facilitating action on the motor structures and he interpreted symptoms such as asthenia and hypotonia, which are evident in cerebellar lesions, as the result of suppression of this tonic influence.

Several mechanisms can account for the increase in RMT in our patients, and they might act in the brain or the cord, or both. At the cortical level the changes in excitability could have been caused by withdrawal of 
tonic background support of the cerebellum to the motor cortex. ${ }^{6}$ At the spinal level the changes may be generated by the pronounced depression of spindle primary afferent discharge produced by the inactivation of the cerebellum. ${ }^{7}$ The depression of primary afferent discharge of the spindle deprives the homonymous a motor neurons of a strong facilitatory influence.

More conceivably the increase in the RMT may result from disruption of a complex neocerebellar-cortical-spinal system induced by the inactivation of the cerebellum.

Previous studies have reported an opposite effect of the cerebellum on the motor cortex; electrical $^{9}$ and magnetic ${ }^{10}$ cerebellar stimulation produced a phasic inhibition of the motor cortex. Tonic facilitation, suggested by our study, and phasic inhibition produced by cerebellar stimulation are probably due to a different functional state of cerebellar neuronal elements. The tonic facilitation may be due to the continuous activity of deep cerebellar nuclei, ${ }^{11}$ whereas the phasic inhibition may be produced by the electrical or magnetic activation of Purkinje cells, which cause a disfacilitation of motor circuits through an inhibition of deep cerebellar nuclei. ${ }^{12}$

Patient 6 with an ischaemic lesion in the territory of the lateral branch of the left superior cerebellar artery showed a normal RMT bilaterally. The small size of the lesion involving only the anterior part of the rostral cerebellum may be the reason for the normal RMT. Moreover, the finding of a normal RMT in this patient may be explained by the fact that the lesion was confined in the anterior lobe with normal neocerebellar structures. In fact, as first hypothesised by Bremer in 1935,13 it is only the neocerebellum that exerts a tonic facilitating action whereas the paleocerebellum exerts a tonic inhibiting action.
In conclusion, the reduction of the excitability of the motor cortex functionally related to the impaired hemicerebellum in our patients suggests the existence of a facilitating tonic action of the cerebellum on the motor cortex. From a clinical point of view this study shows that threshold measurement may be an additional index for the functional evaluation of central motor circuits by magnetic transcranial stimulation.

1 Dow RS, Moruzzi G. The physiology and pathology of the cerebellum. Minneapolis: Thy Ulogy and pathology of the cerebellum.

2 Barker AT, Jalinous R, Freeston IL. Non-invasive magnetic stimulation of the human motor cortex. Lance 1985;ii:1106-7

3 Day BL, Hess CW, Maertens de Noordhout A, Marsden CD, Mills K, Murray NMF, et al. Direction of curren in magnetic stimulating coils used for percutaneous activation of brain, spinal cord, and peripheral nerve. f Physiol (Lond) 1990;430:617.

4 Caramia $\mathrm{MD}$, Cicinelli $\mathrm{P}$, Paradiso $\mathrm{C}$, Mariorenzi $R$ Zarola F, Bernardi G, et al. Excitability changes of muscular simulation in patients with central disorders. Electroencephalogr Clin Neurophysiol 1991;81:243-50.

5 Luciani L. II cervelletto: nuovi studi di fisiologia normale patologica. Firenze:Le Monier 1891.

6 Murphy JT, Wong YC, Kwan, HC. Afferent-efferent linkages in motor cortex for single forelimb muscles. linkages in motor cortex for sin

7 Gilman S. The mechanism of cerebellar hypotonia. An experimental study in the monkey. Brain 1969;92: 621-38.

8 Gilman S, Marco LA, Ebel HC. Effects of medullary pyramidotomy in the monkey II. Abnormalities of spindle afferent responses. Brain 1971;94:515-30.

9 Ugawa Y, Day BL, Rothwell JC, Thompson PD, Merton PA, Marsden CD. Modulation of motor cortical excitability by electrical stimulation over the cerebellum in man. F Physiol (Lond) 1991;441:57-72.

10 Werhahn KJ, Meyer BU, Rothwell JC, Thompson PD, Day BL, Marsden CD. Reduction of motor cortex excitability by transcranial magnetic stimulation over excitability by transcranial magnetic stimulation over

11 The human cerebellum. F Physiol (Lond) 1993;459:149P. neurones during rapid alternating arm movement in the neurones during rapid alternating arm m

12 Ito M, Yoshida M, Obata K, Kawai N, Udo M. Inhibitory to $M$, Yoshida $M$, Obata $K$, Kawai N, Udo M. Inhibitory
control of intracerebellar nuclei by the Purkinje cell axons. Exp Brain Res 1970;10:64-80.

13 Bremer F. Le cervelet. In: Roger GH, Binet L, eds. Traite de physiologie normale et pathologique. Paris: Masson, 1935;10:39-134. 